BOGDAN SZLACHTA ${ }^{1}$

\title{
CZYMŻE JEST KULTUROZNAWSTWO JAKO DYSCYPLINA NAUKOWA OKREŚLONA W POLSKIM PRAWIE?
}

Słowa kluczowe: kulturoznawstwo, dyscyplina naukowa, polskie prawo

Kiedy pełniłem funkcję dziekana Wydziału Studiów Międzynarodowych i Politycznych, jednej z najmłodszych jednostek podstawowych najstarszej polskiej wyższej uczelni, Uniwersytetu Jagiellońskiego w Krakowie, mimo iż sam nie miałem aspiracji do prowadzenia badań w zakresie stosunkowo nowej dyscypliny naukowej, jaką jest kulturoznawstwo, próbowałem zrozumieć, czym jest ta dyscyplina, w trakcie przygotowywania wniosku o uprawnienia do nadawania w niej stopnia doktora. Wówczas, w 2008 roku, wiedziałem, że od kilku już lat na wydziale są realizowane programy studiów I i II stopnia na kierunku kulturoznawstwo (obok trzech innych: politologii, stosunków międzynarodowych i europeistyki) dla studentów aż dziewięciu różnych specjalności: obok kulturoznawstwa międzynarodowego oraz stosunków etnicznych i migracji międzynarodowych również amerykanistyki i latynoamerykanistyki, studiów bliskowschodnich i studiów dalekowschodnich, rosjoznawstwa i ukrainoznawstwa, a także prowadzonych w języku angielskim studiów transatlantyckich. Wydział, w siódmym roku istnienia, kształcił blisko pięć tysięcy studentów oraz ponad trzystu doktorantów (blisko połowa kształcących się na trzech stopniach studiowała specjalności kulturoznawcze)², a wielu jego pracowników

\footnotetext{
${ }^{1}$ Prof. dr hab.; Uniwersytet Jagielloński w Krakowie; e-mail: bogdan.szlachta@uj.edu.pl.

${ }^{2}$ Wydział prowadził trzystopniowe studia na kierunku kulturoznawstwo w ramach unikatowych specjalności, które obejmują wiedzę o kulturze kilku ważnych regionów
} 
prowadziło badania nad rozmaitymi kulturami (Ukrainy i Rosji, społeczeństw azjatyckich oraz południowoamerykańskich, Stanów Zjednoczonych Ameryki i Kanady, jako że na wydziale działał między innymi jedyny wówczas w Polsce ośrodek o nazwie Zakład Kanady, w którym już wtedy prowadzono badania kulturoznawcze nad kanadyjską wielokulturowością, kulturą franko-kanadyjską w Quebecu, nad kulturami grup etnicznych żyjących w Kanadzie oraz nad kanadyjskimi natives, tj. Indianami, Inuitami i Metysami), wreszcie nad tożsamością europejską (w związku z kierunkiem europeistyka).

Zarówno studia te, jak i badania dotyczyły poszczególnych regionów świata, w szczególności właściwych im - a różnych - kultur. Prócz przedmiotów zaliczanych w tamtym okresie do tzw. minimów programowych dla kierunku studiów kulturoznawstwo studentom zaproponowano, by zdobywali wiedzę o danej tradycji lub danych tradycjach kulturowych, przy czym nacisk kładziono na elementarną znajomość języka poznawanego regionu, by wiedzę tę można było czerpać wprost ze źródeł należących do danej kultury czy danych kultur, a nie wyłącznie z opracowań obcych (głównie anglojęzycznych), niekiedy nieoddających lub nieoddających w pełni

świata: Ameryki Północnej i Ameryki Południowej, Rosji i Ukrainy oraz Bliskiego i Dalekiego Wschodu. W trakcie zajęć studenci zapoznawali się z historią kultur od ich zarania do współczesności, z właściwymi im dokonaniami w zakresie literatury, filmu i teatru, duchowości i filozofii, kultury politycznej i prawnej, kultury ludowej i masowej, kultury języka, jak również z historią i geografią poszczególnych regionów, opierając swe studia na dobrej znajomości języków właściwych poszczególnym kulturom, co znakomicie ułatwia uchwycenie zagadnień semiotycznych. Wyjątkowość podejścia przyjętego na wydziale polegała bowiem na dogłębnych studiach jednej konkretnej kultury, przez co student stawał się specjalistą z zakresu danego regionu świata wyposażonym we wszechstronną wiedzę zaczerpniętą ze źródeł bezpośrednich, a nie z opracowań, głównie anglojęzycznych, co stało się praktyką nazbyt powszechną. Specyfiką tych studiów było także to, że studenci nie zapoznawali się z wyizolowanym aspektem kultury, lecz studiowali kompleksowo wiele aspektów, w ich wzajemnym powiązaniu i z uwzględnieniem ogólnej wiedzy kulturoznawczej z zakresu teorii, historii, filozofii, socjologii i antropologii kultury. Studia prowadzone były w oparciu o wypracowane przez pracowników wydziału oryginalne programy ( $z$ uwzględnieniem ministerialnych standardów kształcenia dla poszczególnych kierunków i poziomów kształcenia), zgodne z zakresem badań prowadzonych przez nich w przestrzeni kulturowej najważniejszych regionów świata.

Przedstawiony wywód i liczne inne fragmenty niniejszego tekstu zawdzięcza autor współpracy Pana Profesora Andrzeja Dudka, Prodziekana ds. dydaktycznych, znakomitego znawcy i zagadnień w tekście poruszanych, i historii w nim opowiadanej. 
charakterystyki danej kultury czy danych kultur, być może nawet dotkniętych niejakim „europocentryzmem" ${ }^{3}$.

Wypracowany na wydziale model kształcenia kulturoznawczego odzwierciedlał takie ujęcie wiedzy o kulturze, które Andrzej Mencwel czynił jej aspektem, gdy pisał, że

wiedza o kulturze, jakiejkolwiek nazwy użyjemy na jej określenie, nie jest umieszczona ponad czy poza kulturą. Jest ona aspektem, być może szczególnie racjonalnym, intelektualnym, samoświadomym, tej samej rzeczywistości, którą bada i która w badaniu tym staje się dla niej przedmiotem ${ }^{4}$.

Z tego względu w prowadzonych na wydziale badaniach kulturoznawczych i programach dydaktycznych wielką wagę przywiązywano do poznawania także regionalnych koncepcji kultury, wizji kulturoznawstwa, koncepcji dialogu międzykulturowego i lokalnych koncepcji tożsamości kulturowej. Czyniono tak, mając świadomość, iż wielu pracowników wydziału nie tylko należy do międzynarodowych stowarzyszeń naukowych, ale i współpracuje z zagranicznymi placówkami naukowymi w zakresie badań od dawna stanowiących tam dyscyplinę odrębną (dla przykładu: ang. cultural studies, fr. études culturelles, niem. Kulturwissenschaft czy ros. культурология). Wiedzieliśmy również, że skoro Konstytucja RP z 1997 roku określa Polskę mianem „demokratycznego państwa prawnego" (art. 2), to - obok doświadczeń i reguł przyjętych w zagranicznych środowiskach naukowych - konieczne jest odniesienie naszego pojmowania kulturoznawstwa, eksponującego badania i studia wielu i różnych kultur

${ }^{3}$ Kilka jednostek wewnętrznych wydziału, w tym Instytut Amerykanistyki i Studiów Polonijnych, Instytut Rosji i Europy Wschodniej, Instytut Studiów Regionalnych (wraz z Katedrą Bliskiego i Dalekiego Wschodu) oraz Katedra Ukrainoznawstwa, prowadziło wówczas studia na kierunku kulturoznawstwo w ramach tych specjalności, a także szeroko zakrojone badania nad kulturami wybranych regionów. Niepodobna nie doceniać znaczenia badań naukowych o charakterze kulturoznawczym prowadzonych w tych jednostkach przez pracowników naukowo-dydaktycznych posiadających stopnie naukowe nie w zakresie nowej stosunkowo dyscypliny, jaką było wówczas kulturoznawstwo, lecz w dyscyplinach wcześniej określonych w polskim prawie, jak socjologia, językoznawstwo, literaturoznawstwo, historia i filozofia, rzetelnie a wnikliwie analizujących zjawiska kulturowe w krajach Europy, obu Ameryk, Rosji i na Ukrainie, a także w Azji, również w związku z procesem globalizacji, dotykającym wszak rozmaitych zjawisk kulturowych.

${ }^{4}$ A. Mencwel, Wiedza o kulturze współczesnej, [w:] idem, Wyobraźnia antropologiczna. Próby i studia, Warszawa 2006, s. 27. 
zarówno w ich dawnym, jak i obecnym kształcie, do aktów normatywnych z jednej i aktów nienormatywnych oraz innych dokumentów z drugiej strony. W szczególności wzięliśmy pod uwagę treść pisma skierowanego 31 marca 2006 roku do Dziekana Wydziału Studiów Międzynarodowych i Politycznych UJ przez Przewodniczącego Komisji do spraw Stopni i Tytułów Naukowych, prof. dr. hab. Janusza Tazbira (nr BCK-Org.-110/2006). Znaleźliśmy tam stwierdzenie o toczących się dyskusjach „w sprawie zakresu nauki, którego dotyczy dyscyplina kulturoznawstwo". Dyskusje te, czytamy dalej, nie zostały dotąd zwieńczone wiążącymi konkluzjami; być może, podobnie jak w wielu innych obszarach życia publicznego, ich uczestnicy oczekują na rozstrzygnięcia ustawodawcy lub organów administracji publicznej, które ustalą ów zakres (uwzględniając wyniki toczącej się debaty merytorycznej). Skoro debata „w sprawie zakresu nauki, którego dotyczy dyscyplina kulturoznawstwo" nie zakończyła się, a wskazówki dotyczące granic tej dyscypliny można już było odnaleźć w aktach normatywnych, to na tych ostatnich postanowiliśmy oprzeć wywód uzasadniający wniosek o przyznanie wydziałowi uprawnień do nadawania stopnia naukowego doktora nauk humanistycznych w dyscyplinie kulturoznawstwo. W piśmie Przewodniczącego Centralnej Komisji, pierwszym dokumencie, który dawał wskazówki co do określenia, czy wydział miał podstawy do podjęcia takich starań, znajdujemy jednak ustalenie zawężające:

przez kulturoznawstwo rozumiemy naukę o kulturze współczesnej (tj. mniej więcej od połowy ubiegłego stulecia), jej osiągnięciach i trudnościach, na jakie napotyka, oraz o roli mass mediów w upowszechnianiu tej kultury.

Nowa dyscyplina, uznana za odrębną dopiero w 2005 roku5, zogniskowana jest więc zasadniczo na badaniu kultury współczesnej (lecz czy tylko polskiej?), tworzonej zaledwie („mniej więcej”) w ostatnim półwieczu, oraz na roli, jaką w jej upowszechnianiu odgrywają mass media. Teza ta została zarazem opatrzona zastrzeżeniem, że

badania kulturoznawcze mogą obejmować socjologię kultury, jak również jej związki z wielowiekowym dorobkiem cywilizacyjnym polskim i ogólnoeuropejskim, przy czym winny być one prowadzone pod znakiem interdyscyplinarności.

${ }^{5}$ Uchwała Centralnej Komisji do spraw Stopni i Tytułów z dnia 24 października 2005 roku w sprawie określenia dziedzin nauki i dziedzin sztuki oraz dyscyplin naukowych i artystycznych (M.P. Nr 79, poz. 1120). 
Można wnioskować, że badania kultury współczesnej winny być uzupełniane badaniami historycznymi („,wielowiekowy dorobek cywilizacyjny”) dotyczącymi dokonań zarówno polskich, jak i ogólnoeuropejskich. Nawet ten wniosek, oparty na zastrzeżeniu zawartym w przywoływanym piśmie, był dla nas kontrowersyjny, zamykał bowiem perspektywę badawczą nie tylko temporalnie (zaledwie pół wieku wstecz, choć z „oddechem historycznym"), ale także przestrzennie (tylko dziedzictwo polskie i „ogólnoeuropejskie", bez względu na to, co przez to ostatnie rozumiał nadawca pisma).

Kluczowe znaczenie we wstępnym określeniu zakresu dyscypliny kulturoznawstwo miała definicja kultury - wedle wskazań nadawcy pisma to bowiem jej elementy, "tworzone w ostatnim półwieczu”, miały być zasadniczym przedmiotem badań kulturoznawczych (oraz rola mediów w ich upowszechnianiu i uzupełniający tamte „wymiar historyczny”). Jeśli uznamy, że elementami tymi są film i teatr, malarstwo i literatura, to zasadność wniosku wydziału uwarunkowana była obecnością w dokonaniach pracowników jednostki zgłaszającej badań dotyczących tych składników kultury współczesnej. Wobec stosunkowo krótkiego okresu istnienia kulturoznawstwa jako dyscypliny odrębnej i nieposiadania przez pracowników wydziału stopni naukowych z tej dyscypliny decydujące znaczenie dla zasadności wniosku miało tedy ustalenie, iż dorobek pracowników sygnujących go miał walor kulturoznawczy, skoro Prezydium Centralnej Komisji do spraw Stopni i Tytułów Naukowych, analizując treść art. 6 Ustawy z dnia 14 marca 2003 roku o stopniach naukowych i tytule naukowym oraz o stopniach i tytule w zakresie sztuki (Dz. U. Nr 65, poz. 595 ze zm.), uznawało, że

w ramach obowiązującego prawa dopuszczalne jest zaliczenie do minimum kadrowego $w$ danej dyscyplinie osoby z tytułem profesora tej dziedziny nauki lub sztuki, do której dana dyscyplina należy.

Prezydium CK dopuszczało też,

że w ramach dziedziny uzyskanego tytułu profesora dana osoba reprezentuje tę dyscyplinę, której dotyczy jej główny, zwłaszcza pohabilitacyjny, dorobek naukowy lub artystyczny.

W takich przypadkach konieczne było jednak „przedstawienie udokumentowanych argumentów, że warunek ten jest spełniony" („dokumentację argumentów" przedstawiliśmy we wniosku w odniesieniu do 
pracowników posiadających tytuł profesora nauk humanistycznych i pracowników posiadających stopień naukowy doktora habilitowanego $\mathrm{w}$ innych dyscyplinach niż kulturoznawstwo, będących jednak dyscyplinami wobec niego pokrewnymi, jak wynikało z zapisów przedstawionych na stronie internetowej CK - data ostatniego dostępu: 17 IV 2009).

Istotny dla naszych rozważań był również drugi dokument, akt nienormatywny, jakim była decyzja Centralnej Komisji do spraw Stopni i Tytułów z dnia 11 kwietnia 2007 roku (nr BCK-I-U-427, 429/2006), po raz pierwszy odmawiająca przyznania wydziałowi uprawnienia do nadawania stopnia naukowego doktora nauk humanistycznych $w$ dyscyplinie kulturoznawstwo. W dokumencie tym pojawiało się stwierdzenie, iz „w wykazach publikacji większości pracowników Wydziału” dominuje perspektywa właściwa dla takich dyscyplin, jak prawo, politologia, socjologia, historia, ekonomia, literaturo- czy językoznawstwo (być może ocena ta oparta była na analizie wykazów publikacji pracowników wydziału, w których obok prac osób specjalizujących się w zakresie kulturoznawstwa występowały publikacje innych pracowników naukowych zasiadających w Radzie Wydziału, aktywnych w innych dyscyplinach, w szczególności wskazanych w negatywnej dla wydziału decyzji CK).

Z kolei w sentencji trzeciego dokumentu, kolejnej decyzji Centralnej Komisji do spraw Stopni i Tytułów z dnia 27 października 2008 roku (nr BCK-I-U-235/2008), po raz drugi odmawiającej przyznania wydziałowi uprawnienia do nadawania stopnia naukowego doktora nauk humanistycznych w dyscyplinie kulturoznawstwo, znajdujemy odmienne stwierdzenia. Czytamy w niej bowiem, iż „Wydział jest mocnym ośrodkiem studiów kulturowych, lecz nie kulturoznawstwa". Tym razem Centralna Komisja nie eksponowała już dominacji w „wykazach publikacji większości pracowników Wydziału" takich dyscyplin, jak prawo, politologia, socjologia, historia, ekonomia, literaturoznawstwo, językoznawstwo, lecz zwracała uwage na „brak kulturoznawczej tożsamości badań nad kulturą prowadzonych na Wydziale", mimo bycia przezeń - co szczególnie istotne i co warte podkreślenia raz jeszcze - „mocnym ośrodkiem studiów kulturowych”. W kolejnych fragmentach sentencji przywoływanej decyzji znajdujemy stwierdzenia, iż „kulturoznawstwo jest dyscypliną młodą, ale wypracowało już swoje teoretyczno-metodologiczne podstawy, pozwalające wyodrębnić go [sic!] spośród sąsiednich dyscyplin humanistycznych". Przedmiotem kulturoznawstwa "jest kultura” (podobnie jak w piśmie Przewodniczącego CK), natomiast „właściwym przedmiotem badań prowadzonych na Wydziale” jest 
nie ona, lecz „literatura, religia, stosunki społeczne, historia myśli itd.". Wydaje się, że - zgodnie z treścią rozstrzygnięcia CK przedstawionego $\mathrm{w}$ decyzji - obszary te nie należą do kultury, lecz są przedmiotem odmiennych i odrębnych badań prowadzonych w ramach innych dyscyplin naukowych.

Wyłączenie tych obszarów z kultury, a co za tym idzie - z kulturoznawstwa (przypomnijmy: literatura, religia, stosunki społeczne, historia myśli itd.), powodowało w naszej opinii, że pole zainteresowań nowej dyscypliny znacznie oddalało ją od dyscypliny określanej w świecie anglojęzycznym terminem cultural studies, wiązanej najczęściej z tzw. szkołą Birmingham. Jak pisze Janusz Barański w tekście Kulturoznawstwo - nowa superdyscyplina nauk o człowieku?, choć

tłumaczenie cultural studies jako „kulturoznawstwo" jest poprawne, [to] istnieją jednak poważne różnice historyczne, teoretyczne i metodologiczne między badaniami wywodzącymi się z tradycji Birmingham a [badaniami] polskimi,

co sprawia, że polskie kulturoznawstwo „ma wciąż mało wspólnego z tym zachodnim" (dodajmy na marginesie, iż w piśmie Przewodniczącego CK zwracano uwagę na potrzebę prowadzenia badań interdyscyplinarnych nad kulturą).

Zachodnie studia kulturowe - kontynuuje Barański - [stały się] miejscem spotkania badaczy z zakresu antropologii, historii, socjologii, teorii literatury, filozofii, politologii, historii sztuki, filmoznawstwa, filologii, architektury, religioznawstwa, psychologii, geografii, by wskazać tylko dyscypliny znane w polskim systemie nauki ${ }^{6}$.

Nie tylko w związku z tymi ustaleniami zadawaliśmy sobie pytanie, czy kulturoznawstwo polskie, „oddalone” od „zachodnich studiów kulturowych”, nie ma być miejscem takiego „spotkania interdyscyplinarnego”. "Spotkania", do którego przecież dochodziło na wydziale skupiającym specjalistów różnych dyscyplin nauk humanistycznych działających w zakresie

${ }^{6}$ J. Barański, Kulturoznawstwo - nowa superdyscyplina nauk o człowieku?, [w:] Tożsamość kulturoznawstwa, red. A. Pankowicz, J. Rokicki, P. Plichta, Kraków 2008, s. 36. I przywołana praca zbiorowa, i liczne inne (m.in. Kulturowe i społeczne wyzwania współczesności, red. M. Banaś, T. Paleczny, K. Warmińska, Kraków 2010; Przeszłość we współczesnej narracji kulturowej, t. 1 i 2, red. P. Biliński, P. Plichta, Kraków 2011; W kręgu kultury. Szkice metodologiczne, red. A. Pankowicz, Kraków 2011) ogłoszone zostały przez pracowników wydziału. 
cultural studies, na co zresztą zwrócono uwagę w przywoływanej decyzji CK, zaznaczając, iż „Wydział gromadzi wybitnych badaczy i ma poważne osiągnięcia w zakresie politologii, literaturoznawstwa, socjologii" (zatem przynajmniej kilku dyscyplin wymienianych przez Barańskiego). Mimo to w decyzji stwierdzono zarazem, że wydział „nie przyjął podstaw badań kulturoznawczych i w tej dyscyplinie prowadzi je w ograniczonym zakresie", co tym samym jednoznacznie wskazywało, iż „podstawy badań kulturoznawczych" nie są tymi, które wspierają „zachodnie studia kulturowe”. Sugestia Barańskiego, iż „korzenie kulturoznawstwa” można w Polsce odnaleźć „co najwyżej w filozoficznej szkole J. Kmity", jest jednak problematyczna, gdyż „zakres tematyczny, teoria i metodologia współczesnego polskiego kulturoznawstwa mają [...] - zdaniem tego autora - niewiele wspólnego [nawet] z tą szkołą [tj. szkołą Kmity]"7.

Jeszcze jeden element sentencji decyzji z 2008 roku wart jest przywołania: „Wydział prowadzi badania rusycystyczne, ukrainistyczne, amerykanistyczne, europeistyczne $i$ inne, natomiast $w$ niewielkim stopniu kulturoznawcze". Tymczasem, jak twierdzi Andrzej Radomski w tekście Kulturoznawstwo jako postnauka (ogłoszonym także w pracy zbiorowej Tożsamość kulturoznawstwa), „od samego początku istnienia kulturoznawstwa deklarowanym jego przedmiotem badań, była [...] kultura, jej poszczególne sfery i aspekty funkcjonowania" ${ }^{8}$. Autor zaznacza, że tak określony przedmiot dyscypliny nauki ma charakter pewnego bytu (pewnej realności), który właśnie „można nazwać kulturą” - jedną „kulturą ludzką”, ujmowaną często jako „zasada regulująca życie społeczeństwa we wszystkich jego dziedzinach"; zauważa zarazem, że zdano sobie sprawę, iż taka ,jedna

${ }^{7}$ J. Barański, Kulturoznawstwo..., op. cit.

${ }^{8}$ A. Radomski, Kulturoznawstwo jako postnauka, [w:] Tożsamość kulturoznawstwa, op. cit., s. 134. Pracę zbiorową Tożsamość kulturoznawstwa przygotowali pracownicy wydziału, a jej wydanie zostało wsparte przez wydział. Jest ona owocem namysłu nad istotą i granicami kulturoznawstwa, podjętego jesienią 2007 roku na konferencji zorganizowanej przez działający na wydziale Instytut Studiów Regionalnych, koniecznego w jednostce, której CK kilka miesięcy wcześniej odmówiła przyznania uprawnienia do nadawania stopnia naukowego doktora nauk humanistycznych w dyscyplinie kulturoznawstwo (pierwszy wniosek wydziału). Namysł ten jednak nie był „okazjonalny”, lecz został podjęty wcześniej i jest stale podtrzymywany jako fundamentalny w dwóch jednostkach Instytutu Studiów Regionalnych: Katedrze Teorii i Historii Badań Kulturoznawczych oraz Zakładzie Semiotyki i Socjologii Kultury (w grudniu 2008 roku odbyła się kolejna konferencja współorganizowana przez te jednostki - „Dialog na pograniczu kultur i cywilizacji”, a w maju 2009 roku sympozjum „Tożsamość kultur. Tożsamość cywilizacji”). 
ogólnoludzka kultura” nie istnieje, każde bowiem społeczeństwo „ma swoistą kulturę"9. Już to stwierdzenie (i dalszy wywód Radomskiego) łączy się z postulatem poznawania i badania każdej z wielu kultur - ich poznawania i badania jako „określonych, oddzielnych całości”. Tego typu badania podejmowano zaś na wydziale, nakierowując je na takie „określone, oddzielne całości”, jakimi są kultury amerykańska i rosyjska, ukraińska i polska choćby. Więcej nawet: dominujący już w drugiej połowie XX wieku krytyczny ogląd w zakresie ujmowania kultur jako „określonych, oddzielnych całości" między innymi wobec procesów migracyjnych (zwróćmy w związku z tym uwagę na badania nad migracjami prowadzone wówczas i dzisiaj przez pracowników wydziału) i wymierania plemion homogenicznych, który wymaga traktowania kultury tylko jako „informacji i tożsamości dostępnych w globalnym supermarkecie" ${ }^{\prime 10}$, także znajdował i wciąż znajduje odzwierciedlenie $w$ dokonaniach pracowników wydziału, którzy badali zagadnienia wielokulturowości i stosunków międzykulturowych. Istnienie jednostek, które koncentrują się na prowadzeniu badań nad „tożsamością kulturoznawstwa” właśnie, a nie nad „studiami kulturowymi” (dystynkcja kluczowa w zarzucie dyskwalifikującym kolejne starania wydziału o uprawnienia), ma znaczenie nie tylko dla wydziału, ale także dla nauki polskiej, skoro proces ustalania "granic kulturoznawstwa" trwał pod koniec pierwszej dekady XXI stulecia (czy się zakończył do przełomu lat 2016/2017, nie jestem w stanie orzec). Udział w tym procesie pracowników wydziału dokumentują dokonania teoretyczne, które zostały opublikowane w przywoływanej pracy zbiorowej przygotowanej również przez nich, a zawierającej teksty dotyczące istoty i granic kulturoznawstwa (ich dorobek należy do kilku obszarów, od zagadnień metodologicznych, poprzez socjologię, filozofię i antropologię kultury, aż po historię kultury, aspekty komunikacji społecznej i medioznawstwa).

Związani, podobnie jak wszystkie jednostki działające między innymi w sferze szkolnictwa wyższego i wszystkie organy orzekające, obowiązującymi przepisami prawnymi, byliśmy świadomi, że - zgodnie z art. 6 ust. 1 Ustawy z dnia 14 marca 2003 roku o stopniach naukowych i tytule naukowym oraz stopniach i tytule w zakresie sztuki - uprawnienie do nadawania stopnia doktora

\footnotetext{
${ }^{9}$ Ibidem.

${ }^{10}$ Ibidem, s. 136.
} 
może otrzymać jednostka organizacyjna, która zatrudnia w pełnym wymiarze czasu pracy co najmniej osiem osób posiadających tytuł profesora lub stopień doktora habilitowanego, reprezentujących dziedzinę nauki lub dziedzinę sztuki, w zakresie której jednostka organizacyjna ma otrzymać uprawnienie.

W naszym przekonaniu liczba osób spełniających te wymagania pięciokrotnie przekraczała na wydziale wymaganą liczbę ośmiu osób (jeśli uwzględniać pracowników posiadających tytuł profesora lub stopień doktora habilitowanego w dziedzinie nauk humanistycznych, to ich liczba przekracza czterdzieści, licząc samych politologów i socjologów, filozofów i historyków, nie licząc natomiast - stosunkowo nielicznych na wydziale ekonomistów czy prawników, którzy także zasiadają w jego organie kolegialnym). $Z$ kolei przepis art. 6 ust. 3 stanowi, że uprawnienie między innymi do nadawania stopnia doktora

może obejmować tylko te dyscypliny naukowe lub artystyczne, które w danej jednostce organizacyjnej są reprezentowane przez co najmniej pięć osób zatrudnionych w pełnym wymiarze czasu pracy, posiadających tytuł profesora lub stopień doktora habilitowanego.

Wykazując aż dwudziestu jeden "sygnatariuszy” (liczba ponad czterokrotnie przekraczająca wymaganą), w tym dwanaście osób posiadających tytuł profesora i dziewięć posiadających stopień doktora habilitowanego, i uwzględniając przywoływane już rozstrzygnięcie Prezydium CK dotyczące treści art. 6 przedmiotowej ustawy oraz wymagania przez nią stawiane, dotyczące co najmniej rocznego okresu zatrudnienia w starającej się o uprawnienia jednostce (warunek spełniony w każdym przypadku), mieliśmy nadzieję, że CK uzna, iż sygnujące wniosek osoby zatrudnione na wydziale, posiadające tytuł profesora lub stopień doktora habilitowanego w pokrewnych dziedzinach naukowych (art. 6 ust. 5), spełniają warunki, o których mowa w poprzedzających ust. 5 przepisach art. 6 przedmiotowej ustawy. Mieliśmy ją, gdyż dokonania naukowe (i dokonania w zakresie kształcenia młodej kadry) sygnujących wniosek pracowników wydziału dotyczyły teorii, filozofii, antropologii, socjologii i historii kultury, literackiego wymiaru kultur, relacji języka do kultury, wreszcie podstawowych form kultury (film, teatr, plastyka itd.) zarówno ostatniego półwiecza, jak i okresów wcześniejszych, a zatem zagadnień zaliczanych do obszarów badawczych identyfikowanych jako należące do kulturoznawstwa. Mieliśmy ją tedy, sądząc, iż dorobek pracowników naukowych wydziału sygnujących wniosek miał 
charakter kulturoznawczy, mimo że zdobywali oni stopnie i tytuły naukowe w dziedzinie nauk humanistycznych w ramach innych dyscyplin niż - nieistniejące do niedawna - kulturoznawstwo. Stopnie zdobyte przez nich w zakresie socjologii, literaturoznawstwa, historii czy filozofii uzyskane zostały jednak na podstawie prac z zakresu socjologii kultury, analizy zjawisk kulturowych przez pryzmat piśmiennictwa traktowanego jako integralna część kultury, historii kultury, kulturowo-regionalnych uwarunkowań sztuki, kulturowych aspektów myśli filozoficznej lub religijnej czy kulturotwórczej roli religii. Dla rozwoju nowo powstałej dyscypliny kulturoznawstwa obecność wątków podejmowanych w ich pracach badawczych wydawała nam się nie tylko pożądana, ale i niezwykle korzystna, a nawet niezbędna. Wykładowcy i badacze, którzy z powodu braku kulturoznawstwa w polskim rejestrze dyscyplin naukowych zmuszeni byli zdobywać stopnie $w$ ramach istniejących wówczas dyscyplin, mogli przecież rozwijać badania kulturoznawcze, niekiedy znakomicie przyczyniając się do zwiększenia ich zakresu i wzbogacenia o nowe wątki, przez co wnosili swój wkład w rozwój kulturoznawstwa. Pracownicy posiadający dyplomy doktorów lub doktorów habilitowanych w dyscyplinie socjologii podejmowali badania nie tylko ściśle teoretyczne i metodologiczne, ale także traktujące o współczesnej i dawniejszej kulturze Brazylii, Bliskiego i Dalekiego Wschodu czy Ameryki Północnej; ci, którzy uzyskali stopień doktora habilitowanego w zakresie historii, zajmowali się zjawiskami kulturowymi zachodzącymi między innymi w Federacji Rosyjskiej, Stanach Zjednoczonych Ameryki czy Kanadzie; „dyplomowani jako literaturoznawcy" podejmowali tematykę historyczno-kulturową między innymi obejmującą problematykę kulturoznawczą Rosji, Ukrainy i obu Ameryk (literatura jest często materiałem zawierającym problematykę kulturową bądź stanowi syntezę danej kultury narodowej; większość pracowników posiadających stopień naukowy z literaturoznawstwa pracujących na wydziale należy do Komisji Kultury Słowian Polskiej Akademii Umiejętności); ci wreszcie, którzy legitymują się stopniem doktora habilitowanego w zakresie filozofii, ukazują nie tylko filozoficzne podstawy tzw. kultury zachodniej (obejmującej USA i Kanadę), ale także innych kultur, jak latynoamerykańska, rosyjska, chińska, japońska czy indyjska. Próbowaliśmy wykazać, że sygnatariusze wniosku o uprawnienia zajmują się metodologią kulturoznawstwa (i refleksją nad jego granicami), socjologią kultury, filozofią kultury, historią poszczególnych kultur i ich współczesnych dokonań, komunikowaniem oraz kulturowymi aspektami migracji. W naszym przekonaniu ich dorobek zawierał dokonania z zakresu kulturoznawstwa (jeśli nie był 
ściśle kulturoznawczy lub zdominowany przez elementy wcześniej wskazane jako określające nową w Polsce dyscyplinę naukową); nadawali też oni prowadzonym przez siebie badaniom wymiar kulturoznawczy. Co najmniej połowa samodzielnych pracowników sygnujących wniosek (w liczbie dwukrotnie przekraczającej wymaganą przez ustawę) to badacze z dorobkiem obejmującym problematykę ściśle kulturoznawczą niemal od początku ich aktywności twórczej (fakt, że w dorobku części sygnatariuszy wniosku występują dokonania należące bardziej do dyscyplin pokrewnych niż wprost do kulturoznawstwa, budził w nas przeświadczenie, że wzmacnia to raczej niż problematyzuje nasze starania).

Rozumiejąc, że zakwalifikowanie dorobku sygnatariuszy jest kluczowe dla rozstrzygnięcia zasadności wniosku, prosiliśmy nie tylko o uwzględnienie wyraźnej ewolucji badań prowadzonych przez nich w kierunku kulturoznawstwa, ale także o wzięcie pod uwagę kontekstu dokonań: współpraca kulturoznawców z politologami, badającymi między innymi kwestie globalizacji, stosunków międzykulturowych i historii myśli politycznej; prawnikami, zajmującymi się między innymi dziejami kultur prawnych; ekonomistami, prezentującymi gospodarcze uwarunkowania rozwoju poszczególnych kultur; wreszcie filozofami, analizującymi przemiany stylów myślenia charakterystycznych dla poszczególnych kultur (by nie wspominać historyków i socjologów mających „pokrewieństwo” bardziej oczywiste z badaniami nad kulturą, choćby z ostatniego tylko półwiecza), wzmagała wszak „walor interdyscyplinarny” także ich ustaleń, oczekiwany przecież przez Przewodniczącego CK: interdyscyplinarność badań kulturoznawczych jest przez tę „współobecność" rozmaitych perspektyw wzmacniana, a nie ograniczana; z pewnością należy ją uwzględniać, dostrzegając jednak stale odrębność metodologiczną zróżnicowanych badań kulturoznawczych.

Fakt, iż badania pracowników wydziału wykraczały poza „geograficzny wymiar" wskazany w piśmie Przewodniczącego CK (tylko wymiary „polski i ogólnoeuropejski”, o ile ten drugi ma oznaczać „zachodni”, co nie jest oczywiste), wydawał się nie tylko nie przeszkadzać staraniom o uprawnienia do doktoryzowania w zakresie kulturoznawstwa, ale wręcz je wzmacniać z uwagi zarówno na postępujący proces globalizacji, jak i szczególne miejsce polskiego "dorobku cywilizacyjnego", usytuowanego wszak „na pograniczu" Zachodu i Wschodu. Jak się nam wydawało, podejmowanie przez pracowników wydziału badań nad dorobkiem kultur „obu płuc Europy", nad wielością i zróżnicowaniem kultur na wszystkich kontynentach nie tylko wzbogacało naukę o kulturze współczesnej, zakorzenionej wszak 
w dokonaniach dawniejszych, ale również ułatwiało diagnozowanie kierunków, perspektyw i niebezpieczeństw procesów globalizacyjnych, w których wciąż uczestniczy także kultura polska. Więcej nawet: „współobecność” wymiarów kulturoznawczego i politologicznego wydawała nam się konieczna zarówno dla należytego wykształcenia studenta kulturoznawstwa w XXI wieku, jak i dla osiągnięcia możliwie pełnego obrazu kultur w świecie globalizującym się, ale przecież nieznoszącym partykularyzmów. Zrozumienie zjawisk zachodzących w "globalizującym się świecie wielokulturowym” jest znacznie pełniejsze dzięki uwzględnianiu wymiarów analizowanych z jednej strony przez politologów, w tym specjalistów w zakresie stosunków międzynarodowych, z drugiej zaś - przez oddających się badaniom kulturoznawczym. Wydział, wyjątkowy nie tylko w tym względzie, umożliwiał wzajemne „dopełnianie się" politologów i kulturoznawców w badaniach prowadzonych wspólnie i we wspólnie realizowanych programach edukacyjnych. Ich współpraca w zakresie badań naukowych i dydaktyki ułatwiała bardziej adekwatne uchwycenie specyfiki poszczególnych kultur, złożoności procesów globalizacyjnych oraz przyczyn i następstw tak dzisiaj istotnego zjawiska, które określa się mianem wielokulturowości.

Również współtworzący Radę Wydziału stosunkowo nieliczni przedstawiciele nauk prawnych i ekonomicznych przyczyniali się do budowania pełniejszego oglądu kultur zakorzenionych w dawnych, a podlegających ewolucji źródłach, wykraczających poza ramy dotąd w nich samych akceptowane. Ukazywanie ewolucji życia społecznego, myślenia prawniczego czy refleksji filozoficznej i politycznej znakomicie służyło dokładniejszemu rozpoznaniu specyfiki poszczególnych kultur, ich zmienności i trudności na drodze ku ich homogenizacji, nie do końca pewnej (choćby wobec wciąż trwających konfliktów zwanych niekiedy cywilizacyjnymi), choć prawdopodobnej. Poszczególne elementy ewoluującej rzeczywistości społecznej mogły być na tyle rzetelnie rekonstruowane, by dało się je zrozumieć, co z pewnością jest zadaniem nauki, także nauki polskiej, zwłaszcza zaś polskiej humanistyki. Interdyscyplinarność badań wydała nam się konieczna dla należytego uchwycenia mnogości aspektów właściwych współczesnym kulturom i zjawisk zachodzących również w tzw. kulturze zachodniej, rozwijającej się obok innych kultur, współuczestniczącej zaledwie w ewentualnym dążeniu do globalizacyjnego ujednolicenia. Ze względu na swe specyficzne zróżnicowanie wydział zapewniał tę wielowymiarowość czy wieloaspektowość badań, pragnął też obejmować nimi różne kultury, z którymi pozostają w dialogu 
lub w napięciu zarówno „współczesna kultura”, jak i „wielowiekowy dorobek cywilizacyjny polski i ogólnoeuropejski".

Nie wymieniliśmy wszystkich dokumentów przywołanych we wniosku. Wzięliśmy bowiem pod uwagę również te, które w tamtym czasie znaliśmy, jak przybliżająca istotę $\mathrm{i}$ określająca w pewnym zakresie granice kulturoznawstwa jako nowej dyscypliny w polskiej nauce uchwała nr 617/2007 Prezydium Państwowej Komisji Akredytacyjnej z dnia 5 lipca 2007 roku w sprawie kryteriów oceny spełnienia wymagań w zakresie minimum kadrowego, obowiązująca od 1 października 2007 roku. Uchwała ta stanowi w szczególności, iż komisja

przy opiniowaniu wniosków o utworzenie kierunku studiów bierze pod uwagę posiadanie przez pracowników naukowych stopni lub tytułów naukowych i dorobku naukowego w zakresie danego kierunku studiów albo w dziedzinie (dyscyplinie) nauki związanej z tym kierunkiem.

W tymże dokumencie znajdujemy rozstrzygnięcie, iż podstawą uznania dorobku za zgodny z danym kierunkiem studiów jest uzyskany stopień lub tytuł z (wymienionej w załączniku) dziedziny (dyscypliny) nauki lub opublikowany dorobek z (wymienionej w załączniku) dziedziny (dyscypliny) nauki (dotyczy to jednak tylko zatrudnionych na podstawie mianowania lub umowy o pracę w pełnym wymiarze czasu, przy czym dana uczelnia ma stanowić podstawowe miejsce pracy). Wydział nie miał wówczas uczonych posiadających stopień lub tytuł profesora nauk humanistycznych w dyscyplinie kulturoznawstwo, jednak liczne publikacje jego pracowników należały do tej dyscypliny, skoro już w 2001 roku były na tyle znaczące, że wydział otrzymał uprawnienia do prowadzenia kierunku studiów o nazwie kulturoznawstwo. Od tego momentu dorobek ten został znacznie poszerzony, zarówno gdy idzie - zgodnie $z$ treściami wyrażonymi w tymże załączniku do uchwały nr 617/2007 Prezydium Państwowej Komisji Akredytacyjnej z dnia 5 lipca 2007 roku w sprawie kryteriów oceny spełnienia wymagań w zakresie minimum kadrowego - o dorobek naukowy mieszczący się w obrębie danego kierunku studiów (w przypadku kulturoznawstwa w zakresie kierunku mieszczą się jedynie nauki humanistyczne jako dziedzina nauki, w dyscyplinach - historia, tu: historia kultury i historia sztuki), jak i o dorobek naukowy „,w dziedzinie nauki [...] związanej z danym kierunkiem, gdy dorobek ten dotyczy jednego z obszarów nauki lub sztuki wymienionych w kolumnie drugiej lub trzeciej" (pośród dziedzin związanych z kierunkiem 
wymieniono ponownie jedynie nauki humanistyczne, wskazując następujące dyscypliny: etnologia, literaturoznawstwo [filologia / filologia polska], nauki o sztuce [filmoznawstwo, teatrologia], filozofia [filozofia kultury, estetyka], nauki o poznaniu i komunikacji społecznej [medioznawstwo] oraz socjologia [socjologia kultury]; niemal w każdej z tych dziedzin dorobek pracowników wydziału sygnujących wniosek był znaczny).

Kolejnym dokumentem, do którego się odwołaliśmy, był obowiązujący jednostki szkolnictwa wyższego w naszym kraju załącznik nr 59 do rozporządzenia Ministra Nauki i Szkolnictwa Wyższego, w którym przedstawiano „standardy kształcenia dla kierunku studiów kulturoznawstwo”. W części określającej „kwalifikacje absolwenta” studiów pierwszego stopnia wskazano konieczność posiadania przez niego „ogólnej wiedzy dotyczącej zagadnień społecznych tworzących podbudowę dla teoretycznej refleksji o kulturze". Liczni pracownicy wydziału kształcący studentów na kierunku kulturoznawstwo, posiadający stopnie lub tytuł naukowy zwłaszcza w zakresie socjologii i historii, nie tylko prowadzili badania i przekazywali wiedzę dotyczącą zagadnień społecznych, tworzących podbudowę dla teoretycznej refleksji o kulturze, lecz również prowadzili badania analogiczne $z$ innych perspektyw. Przekonanie to wzmacniały dalsze sformułowania zawarte w "standardach kształcenia”. Absolwent kulturoznawstwa powinien bowiem:

rozumieć i umieć analizować zjawiska kultury we wszystkich jej obszarach w skali globalnej, regionalnej, państwowej i lokalnej; znać zasady ekonomiczne i prawne leżące u podstaw organizacji i zarządzania współczesnymi instytucjami kultury. [...] znać i rozumieć współczesne media, sposoby ich oddziaływań, funkcje i znaczenie, jakie pełnią w nowoczesnym społeczeństwie. [...] legitymować się wiedzą z zakresu teatrologii, literaturoznawstwa, regionalistyki. [...] Absolwent powinien znać język obcy na poziomie biegłości B2 Europejskiego Systemu Opisu Kształcenia Językowego Rady Europy.

Wszystkie te wskazania realizowane były na studiach w zakresie kulturoznawstwa przez pracowników prowadzących badania umożliwiające podawanie treści służących właściwemu wyprofilowaniu sylwetki absolwenta studiów pierwszego stopnia. Poziom wykształcenia językowego wymagany $w$ dokumencie ministerialnym był osiągany przez jednostki zatrudniające własnych lektorów, którzy prowadzili kursy językowe w wymiarze przekraczającym wymagania minimalne. Wydział przywiązywał wielką wagę do nauki języków obcych (nie tylko angielskiego, niemieckiego, włoskiego, 
hiszpańskiego czy francuskiego, ale także chińskiego, japońskiego, arabskiego, rosyjskiego i ukraińskiego), szczególnie tych, które pozwalają lepiej zrozumieć poszczególne kultury. Dzięki temu student kulturoznawstwa był przygotowany zarówno do badania tekstów kultury, jak i do uwzględniania w swych poszukiwaniach ujęć i opracowań tworzonych przez kulturoznawców opisujących kultury w różnych regionach świata.

Zawarta we wspomnianym dokumencie ministerialnym wizja dyscypliny, ukazana w pewnym zakresie w profilu absolwenta kierunku, znajdowała odzwierciedlenie $w$ programach studiów kulturoznawczych dostępnych na wydziale oraz w tematach badawczych podejmowanych przez osoby prowadzące zajęcia dydaktyczne na kierunku kulturoznawstwo. Minister wskazał w grupie treści podstawowych dla tego kierunku trzy elementy: (1) kultury z perspektywy różnych dyscyplin naukowych, (2) filozoficzne i metodologiczne podstawy kulturoznawstwa oraz (3) wiedzę o sztuce i literaturze. Każdy z tych elementów znajdował się w polu zainteresowań pracowników naukowych wydziału: pierwszy zajmował historyków, socjologów i filozofów zatrudnionych w instytutach, które oferowały studia w zakresie kulturoznawstwa i europeistyki, oraz tych, którzy prowadzili badania z perspektywy historii literatury i historii teatru czy szeroko rozumianej historii kultury; „różnorodność perspektyw” była realizowana dzięki charakterystycznej dla wydziału wielości reprezentowanych dziedzin i dyscyplin naukowych przez członków Rady Wydziału. Spoglądając z perspektyw właściwych różnym dyscyplinom naukowym, mogli oni oceniać poziom badań dotyczących współczesnych „kultur" (w dokumencie ministerialnym użyta została liczba mnoga, a nie pojedyncza) i ukazywać - wymagane przez dokument ministerialny - „rozumienie i status kategorii »kultura» w wybranych naukach humanistycznych i społecznych, to jest: socjologii, komunikacji społecznej, antropologii kultury”, po to, by przedstawiać „dzieje kultury europejskiej i pozaeuropejskiej interpretowane w perspektywie wybranych koncepcji kultury, postawy społeczne, wyobrażenia, wartości i język w poszczególnych okresach kultury”, by analizować „przedmiot i metody badań socjologii kultury”, a także „sposoby definiowania kultury na gruncie socjologii” w powiązaniu „z charakterystyką zmian relacji między kulturą i społeczeństwem”; by prezentować „socjologiczne ujęcie kultury symbolicznej oraz jej współczesnej, technologicznej transformacji, charakterystyki komunikowania w rozwoju historycznym w kontekście społeczno-kulturowym i w powiązaniu z rozwojem technologii informacyjno-komunikacyjnych” i „problematykę teorii komunikowania” (formy komunikowania, 
szkoły badawcze, modele komunikowania, metody analizy i interpretacji przekazów, zagadnienia komunikowania w kontekście społecznym, problemy globalizacji komunikowania i kultury, komunikowanie międzykulturowe, problematykę społeczeństwa informacyjnego), wreszcie - by podejmować refleksję nad ustaleniami "szkół antropologii kulturowej” i prezentować "dziedziny antropologii kulturowej i przykładowe wzory kultury". Każdy z wymienionych obszarów był przecież przedmiotem rozważań podejmowanych przez pracowników tych jednostek wydziału, które prowadzą studia kulturoznawcze.

Drugi element (,filozoficzne i metodologiczne podstawy kulturoznawstwa") stanowił przedmiot badań pracowników zatrudnionych nie tylko $w$ jednostkach prowadzących studia kulturoznawcze, ale $i \mathrm{w}$ innych jednostkach wydziału, zdolnych kształcić kulturoznawców, skoro dokonują „przeglądu zagadnień filozoficznych w perspektywie historycznej, ze szczególnym uwzględnieniem problematyki ontologicznej i epistemologicznej", ukazują „podstawowe pojęcia metodologii nauk humanistycznych oraz kategorie analizy języka i komunikacji z punktu widzenia filozofii", podejmują namysł nad "logiczną teorią języka" oraz „podstawowymi pojęciami semiotyki”, przedstawiając także "cele i metody badawcze” właściwe semiotyce kultury. Szczególnie istotne są jednak w tym względzie badania prowadzone przez jednostkę o charakterystycznej nazwie: Katedra Teorii i Historii Badań Kulturoznawczych. W polu zainteresowań jej pracowników mieści się namysł nad zagadnieniem „tożsamości kulturoznawstwa” - zagadnieniem fundamentalnym nie tylko dla wniosku, ale także dla ustalenia granic niedawno wyłonionej dyscypliny naukowej.

Wreszcie trzeci element wskazany $w$ dokumencie ministerialnym: „wiedza o sztuce i literaturze”. Wybitni literaturoznawcy, którzy przeszli w 2001 roku na nowo tworzony wydział, wnieśli dorobek z lat poprzednich i znakomicie go rozbudowali, pracując już w naszej jednostce (wykaz dokonań z ostatnich lat znajduje się w załącznikach do wniosku). Treści przewidziane w przywoływanym dokumencie ministra są nie tylko przedmiotem ich dociekań w trakcie zajęć dydaktycznych, ale także $w$ większym lub mniejszym zakresie tematem badań naukowych:

Metodologia badań w obszarze sztuki [...]. Style uprawiania sztuki i literatury. Przedmiot i funkcje literaturoznawstwa. Syntetyczny przegląd kierunków badań literackich w XX stuleciu. Podstawy poetyki. Metody analizy i interpretacji. Literatura a inne sztuki. Perspektywy antropologii literatury. Sytuacja literatury 
we współczesnej kulturze. Podstawy wiedzy z historii i teorii sztuki ze szczególnym uwzględnieniem sztuki najnowszej. Prezentacja twórców oraz dzieł sztuki o znaczącym wpływie na dzieje kultury. Przemiany form ekspresji w sztuce [...]. Sztuka w jej funkcji kreacyjnej oraz funkcji towarzyszenia i dawania wyrazu ludzkiemu doświadczeniu. Teatr i widowiska kulturowe.

Wiele monografii i artykułów naukowych, wspólnie pisanych podręczników i prac zbiorowych poświęcili pracownicy wydziału choćby literaturze rosyjskiej, ukraińskiej, amerykańskiej, latynoamerykańskiej i niemieckiej, znakomicie przyczyniając się do rozwoju polskiego literaturoznawstwa. To samo powiedzieć można o filmoznawcach, badających zwłaszcza filmy amerykańskie i azjatyckie.

Rozporządzenie ministra przedstawiało też „kwalifikacje absolwenta” drugiego stopnia kształcenia w zakresie kulturoznawstwa:

[winien on] posiadać gruntowną wiedzę pozwalającą na rozumienie i interpretację, przez odwołanie się do utrwalonych metodologii naukowych, poszczególnych zjawisk kultury, umieć dostrzegać i opisywać związki istniejące między różnymi obszarami kultury oraz definiować ich specyfikę, posiadać wiedzę o formach instytucjonalnych i sposobach finansowania projektów w dziedzinie kultury, posiadać wiedzę i umiejętności pozwalające na samodzielne rozwiązywanie problemów zawodowych - również w niestandardowych sytuacjach; być przygotowany do samodzielnego wykonywania pracy w instytucjach kultury, samorządach lokalnych w zakresie animacji i organizacji kultury;

wreszcie:

powinien mieć wpojone nawyki kształcenia ustawicznego i rozwoju zawodowego oraz być przygotowany do podejmowania wyzwań badawczych i podjęcia studiów trzeciego stopnia (doktoranckich).

Wszystkie te oczekiwania były spełniane przez prowadzących studia kulturoznawcze, o czym świadczyła w szczególności wielość chętnych do studiowania na studiach trzeciego stopnia na wydziale utworzonym po to, by możliwie wszechstronnie kształcić studentów zainteresowanych współczesnymi zjawiskami kulturowymi w pierwszej, a politycznymi w drugiej dopiero kolejności - pierwsze bowiem daleko bardziej rzutują na drugie niż na odwrót.

Jak już wskazywaliśmy, na Wydziale Studiów Międzynarodowych i Politycznych UJ, zgodnie z przemyślanym i świadomie podjętym planem, 
realizowanym konsekwentnie od momentu powstania jednostki, prowadzono badania obejmujące dwie dyscypliny naukowe: kulturoznawstwo i nauki o polityce. Pracownicy wydziału badali problemy niemal całego świata zamieszkiwanego przez gatunek ludzki, a przy pomocy obu zakresów badania te czynili coraz bardziej wszechstronnymi i interdyscyplinarnymi. Kulturoznawstwo tak przez nich pojmowane, przez innych postrzegane raczej jedynie jako studia kulturowe, wpisuje się $w$ bogate środowisko badawcze obrazujące współczesne konteksty i wyzwania, jakie stają przed nową dyscypliną naukową w relacjach do wielorakich zmian w samej kulturze, która - mimo mnogości przejawów - jest coraz bardziej inter- oraz transnarodowa, interaktywna i świadoma swojego dziedzictwa, zupełnie nowych wyzwań i tożsamości. Uwrażliwienie na różnorodność kulturową współczesnego świata i wkomponowanie jej w pragmatykę dialogu i współpracy międzykulturowej w obronie zdolnego do rozwoju, otwartego dziedzictwa kultur to szansa, jaką daje tak rozumiane kulturoznawstwo. W ten sposób rozwój tożsamości samej dyscypliny może zostać zintegrowany z nowymi jej możliwościami, realizowanymi w środowisku interdyscyplinarnym, otwartym na problematykę kultury i jej badań.

Wniosek, w którym zawarliśmy przedstawione argumenty, przepadł. Pocieszające jest jednak to, że wniosek kolejny, którego autorzy nie odwoływali się już tak chętnie do uwarunkowań normatywnych, został przyjęty przez Centralną Komisję, dzięki czemu wydział cieszy się (po wielu latach starań) z posiadania uprawnienia do nadawania stopnia naukowego doktora w dyscyplinie kulturoznawstwo. Czy rozwiązuje to jednak problem „granic kulturoznawstwa"? Czy oznacza uznanie, że w tej dyscyplinie mieszczą się badania dotyczące różnych kultur, w tym i kultury polskiej (i innych) na przykład sprzed drugiej wojny światowej? Nie potrafię odpowiedzieć na te pytania. Sądzę natomiast, że należy wciąż je stawiać, by czytelne (wreszcie) rozstrzygnięcie mogło zostać przyswojone przez badaczy i studentów przeświadczonych o tym, że zajmują się kulturoznawstwem. 


\title{
WHAT IS CULTURAL STUDIES AS A SCIENTIFIC DISCIPLINE DEFINED BY POLISH LAW?
}

\begin{abstract}
The author of the article concentrates on the long and difficult process of the Faculty of International and Political Studies (at the Jagiellonian University, Krakow) in obtaining the right to educate students in the field of cultural studies. Problematic issues are described on the basis of Polish law which codifies individual disciplines and fields of science. Paying attention to the fundamental differences between Polish, British, French, German or Russian cultural studies was the starting point for taking a deeper reflection on the essence of what cultural studies is and what it should be, with a diverse and thereby rich structure.
\end{abstract}

Key words: cultural studies, scientific discipline, Polish law 